\title{
The Place of Normativity in the Political Ontology of Ernesto Laclau*
}

\author{
Daniel de Mendonça \\ Universidade Federal de Pelotas, Brazil
}

\begin{abstract}
This article is a reflection on normativity in the field of political theory, with the ontological dimension found in Ernesto Laclau's discourse theory as a presupposition. We base ourselves on the premise that, as a political theorist (rather than a political philosopher), Laclau has developed a political theory with great analytical applicability, which is also significantly useful for thinking about the role and limits of political normativity. We sustain that the normative, widely understood as a set of precepts or politically desirable situations, has a limited place in the area of discourse theory. In order to carry out our proposal, this paper is divided into five parts. Firstly, we deal with the post-foundationalist position found in Laclau's thought. Following that, we present him as a political theorist. We then analyse the notions of ideology and discourse, central to the political ontology present in discourse theory. Following that, we discuss antagonism and dislocation, categories used to explain the incompleteness of social meanings, according to Laclau. Lastly, in the light of the ontological presuppositions presented, we seek to establish the possibilities and limits of political normativity, bearing in mind the discourse theory developed by him.
\end{abstract}

Keywords: Post-structuralism; post-foundationalism; discourse theory; normativity; Ernesto Laclau.

\section{Introduction}

T he work of Ernesto Laclau has been a theoretical effort to present an interpretation of the political as an area specific to and explanatory of social relations, particularly since Hegemony and Socialist Strategy (HSS from now on), co-authored with Chantal Mouffe. In spite of his work sometimes having been "accused" of being abstract,

* http://dx.doi.org/10.1590/1981-38212014000100003 
philosophical, - in a word - "unconcerned" with daily political practices, this is absolutely not Laclau's objective. On the contrary, he calls himself a "political theorist", in the sense that all of his intellectual effort has analytical and normative applicability in the field of politics.

This article is an exercise in thinking about the field of normativity in political theory, based on the ontology present in Laclaunian discourse theory. As we have already stated, we base ourselves on the premise that, as a political theorist (rather than a political philosopher) Laclau seeks to present a political theory with analytical applicability that is also useful for thinking normatively. Considering this theoretical perspective, we sustain that normativity is inexorably dependent on the conception of political ontology elaborated by him, the main presuppositions and elements of which will be explored in this article.

To this end, the paper is divided into five parts. Firstly, we will deal with the post-foundationalist position defended by Laclau. Following that, we will present him as a political theorist. We will then analyse the notions of ideology and discourse, central to the political ontology of discourse theory. Following that, we will discuss antagonism and dislocation, categories used to explain the incompleteness of social meanings, according to him. Lastly, bearing in mind the ontological presuppositions presented, we will seek to establish the possibilities and limits of normativity in view of discourse theory.

\section{Laclau and the post-foundationalist position}

Although it is not the only one, a reasonable starting point for understanding Laclau's work is the awareness that his theoretical effort is related to a post-foundationalist matrix. Post-foundationalism consists of a constant critical questioning of theoretical projects aimed at structuring themselves on an ultimate ground, as if such a ground underlay political practices sensu stricto. One example of this is the economic essentialism in the last instance present in the Marxist tradition (LACLAU and MOUFFE, 1985). Although post-foundationalism is a criticism of an ultimate ground that would explain and close all meanings in a totality called society, according to Marchart, it

"must not be confused with anti-foundationalism or a vulgar and nowadays somewhat out-dated 'anything goes' type of postmodernism, since a post-foundational approach does not attempt to erase completely such figures of the ground, but to weaken their ontological status. The ontological weakening of ground does not lead to the assumption of the total absence of all grounds, but rather to that of the impossibility of a final ground, which is something completely different, as it implies an increased awareness of, on one hand, contingency and, on the other, the political as the moment of partial and always, in the last instance, unsuccessful grounding" (MARCHART, 2007, p. 02). 
Bearing the post-foundationalist presupposition in mind, Laclau structures his notion of the political based on the ascertainment that political relations are always unstable and contaminated by antagonism, precariousness and contingency. Thus, any normative efforts that seek to establish future emancipatory scenarios a priori or to prescribe the best way to make public decisions - such as the Marxist tradition and deliberative theories - are the target of constant criticism by the Argentinian theorist.

Hence, his intention is to demonstrate that any political ground is always provisional and dependent on the actual conditions of its inscription. It is against this backdrop that hegemony acquires a central role in Laclau's perspective, since such a notion has the ability to be both an important tool for social analysis and one for normative prescription, as it presupposes precisely the constant instability of concrete political relations (at the ontic level) and of the ever precarious attempts to normalise "good politics".

Every political ground is discursively structured when it is hegemonised, that is, when a certain political position comes to represent various different social sectors. Thus, hegemony is the moment at which a political decision is made, when a certain discourse is consolidated. However, given the ontological instability of the political, or even, the endless contamination of the ontic by the ontological, all hegemony presupposes counter-hegemony and both can only be known at the moment in which political practices arise as such.

In this way, to Laclau, the constant instability in political relations cannot be perceived as abstract. The author is completely aware that his intellectual project is theoretical in the strictest sense of the term, that is, that all of his thought's structure is aimed at its application to political analysis and action. Hence, we understand that to him, any normative proposal that does not consider post-foundationalist elements is of limited theoretical-scientific value.

\section{Laclau as a political theorist}

Laclau moves between political theory and politics with a very precise objective: his thought is not contained within an eminently philosophical field, given the fact that it has a concern for social analysis, with being a theoretical application tool. This impression is shared by Oliver Marchart:

In the proceedings of a conference on deconstruction and pragmatism, Ernesto Laclau once again began his contribution by reminding us that he is 'writing here as a political theorist rather than a philosopher in the strict sense of the term' [...]. Laclau does not tell us how we should imagine a philosopher 'in the strict sense of the term'; but we can assume that he seeks to differentiate his own 
project - which is exclusively concerned with questions of politics and political theory - from the practice of doing 'pure' philosophy, be it in the sense of an academic discipline or a freely floating mode of metaphysical reasoning without any particular realm of application (MARCHART, 2004, p. 54).

In his interviews, Laclau clearly perceives that his political theory cannot be disassociated from his practice as a social activist, that is, his thought has indeed the normative bias of a radical political theory. Here we cite two excerpts from interviews published in New Reflections on the Revolution of Our Time (NR from now on). The first one clearly illustrates the point at which he highlights the understanding of socio-political phenomena based on two categories central to his theoretical contribution - articulation and hegemony:

The idea of politics as hegemony and articulation, for example, is something that has always accompanied my political trajectory. I remember that in 1984, after many years, I travelled to Buenos Aires with Chantal Mouffe and we were able to consult early works of mine. Chantal was surprised to read my leading articles in Lucha Obrera (of which I had been the editor) of twenty years earlier, in which socialist struggle was already spoken about as the struggle of the working class for the hegemonization of democratic tasks (LACLAU, 1990, pp. 177-178).

The second one reveals in an even clearer fashion the intimate relationship between his theory and the phenomena he seeks to shed light on:

That's the reason why I didn't have to wait to read post-structuralist texts to understand what a 'hinge', 'hymen', 'floating signifier' or the 'metaphysics of presence' were: I'd already learnt this through my practical experience as a political activist in Buenos Aires. Therefore, when today I read Of Grammatology, $S / Z$, or the Écrits of Lacan, the examples which always spring to mind are not from philosophical or literary texts; they are from a discussion in an Argentinian trade union, a clash of opposing slogans at a demonstration, or a debate during a party congress (LACLAU, 1990, p. 200).

From the excerpts above, it is evident that to him his task as a theorist is not to be a "political philosopher in the strict sense of the term", but to produce a theory that explains socio-political phenomena and that simultaneously points to means of social transformation. Therefore, there is not a strict separation between political theory and practice. In this sense, his undertaking has two functions: to be normative and explanatory.

The explanatory side of his theoretical effort is initially clearer when reading his texts. Laclau usually presents his analytical categories and illustrates them with political events. This operation seeks to elucidate the notions employed by him - often considered abstract by his readers - and, at the same time, to demonstrate their explanatory power. 
Grasping his explanatory structure is only possible if one also comprehends the elements that compose it. For example, to understand the notion of hegemony one must be aware of how how it is operationalized from a series of other notions such as elements, moments, articulation, nodal points, and antagonism, among others.

Initially, when reading Laclau's work, the normative aspect does not seem so evident. The key to comprehending it lies precisely in realising that to him, the theoretical and the practical are indissociable. In the introduction of a collection of texts, whose authors use his theoretical structure in empirical analyses, Laclau, having established that the separation between political theory and political practice is an "artificial operation", categorically states that "as theoretical-political categories do not only exist in books but are also part of discourses actually informing institutions and social relations, these deconstructive operations are an integral part of the making of political life" (LACLAU, 1994, p. 02). This means that - at least in Laclau's view - the role of political theory is to be explanatory, but it should also point to a normative line, the true task of the intellectual activist.

We believe it is also important to mention that the normative in discourse theory depends on the explanatory structure of socio-political phenomena built by the author. Here, the normative is not an ideal normative, linked to a hypothetical situation, difficult or impossible to realise. It is a normative limited by structural constraints, but that can be wished for. In a well-known essay published with Chantal Mouffe, Post-Marxism without apologies, answering to criticisms of HSS, they focus on the possibility and place of normativity:

We are living, on the contrary, one of the most exhilarating moments of the twentieth century: a moment in which new generations, without the prejudices of the past, without theories presenting themselves as 'absolute truths' of history, are constructing new emancipatory discourses, more human, diversified and democratic. The eschatological and epistemological ambitions are more modest, but the liberating aspirations are wider and deeper (LACLAU and MOUFFE, 1990, p. 98).

In this passage, the criticism focuses particularly on Marxist theory, understood by Laclau as essentialist and objectivist. Essentialist in the sense that economic determination in the last instance is understood by this tradition to be an a priori truth and a characteristic necessary to every type of social formation. And objectivist in the sense that Marxism does not consider a crucial ontological element: the impossibility of attaining ultimate objectivity. The "objective" is when one believes that an object can be fully constituted. To Laclau, essence and the objective are impossible to attain and every political and social theory that postulates such goals will harm its normative content. What we mean by harming normative content goes back to what we called ideal normativism a short while 
ago, that is, it being practically or completely impossible to realise. Thus, to think normatively, inspired by Laclaunian post-structuralism, is to consider the occurrence of actual political happenings, real political movements ${ }^{1}$.

It is in this sense that the eschatological ambitions of political theory and practice must be looked at more modestly, since there is no such thing as the liberation of humanity, in the Marxian sense of human emancipation. However, paradoxically, the aspirations of liberation are deeper and wider, as a practically infinite range of struggles that can legitimately claim to be hegemonic opens up; that is, these struggles can occupy the ever precarious and contingent space of the political representation of identities connected amongst each other in opposition to a common oppressor. There is therefore no need for the prominence of moral or political leadership by any group, stratum or social class, which results in much freer conditions for identity-based action. In Beyond Emancipation, Laclau is even clearer about the fact that we are living in a theoretical and political moment different from modernity's great eschatological narratives:

Contemporary social struggles are bringing to the fore this contradictory movement that the emancipatory discourse of both religious and modern secularized eschatologies had concealed and repressed. We are today coming to terms with our own finitude and with the political possibilities that it opens. This is the point from which the potentially liberatory discourses of our postmodern age have to start. We can perhaps say that today we are at the end of emancipation and at the beginning of freedom (LACLAU, 1996, p. 18).

This is a decisive point for understanding Laclau as a post-structuralist political theorist. Because it presupposes that social dynamics trail an undecidable path, his theory does not allow forecasting of future political scenarios that might be even slightly defined a priori. Given this, the role of theory is, firstly, to get to know the ontological elements of the political, that is, to promote a reflection on the political as such. This reflection touches on knowledge of discourse as a central ontological category. To understand how discourse is formed and how its existence is precarious and contingent helps us understand why normative formulations aimed at "freezing" the inconstant flux of life and social relations are innocuous.

1 This is precisely the normative task undertaken by Aletta Norval, inspired on Laclau's work: "(...) the aim of this exercise, though theoretical in character, is not to produce an account of democratic discourse that is abstracted from the 'stream of life' and removed from each and every context. There is no presupposition here that political grammars in general, and democratic forms of argumentation in particular, could or should be abstracted from ordinary contexts, and from the interests and passions that inspire engagement in democratic politics in the first instance. This desire to separate politics from the concerns of the ordinary usually stems from a Platonic denigration of rhetoric and as excessive valorization of the claims of reason" (NORVAL, 2007, pp. 61-62). 


\section{Ideology and discourse}

Much is said about the fact that we live today in era marked by the end of ideologies, therefore, to speak of the ideological seems to be to propose a senseless discussion. However, this depends on how we define Ideology. If we believe that Ideology is constituted in false consciousness (or alienated consciousness), in the sense of classical Marxism, then we would undoubtedly be dealing with an out-dated notion.

If, on the other hand, we base ourselves on the $20^{\text {th }}$ century topos that in the West there were two hegemonic ideologies - the capitalist (right) and the socialist (left) - and believe that we are in the presence of tight political models, or, even more seriously, transhistorical ones, then we would be making a fatal analytical error. From this perspective, the greatest problem we identified in political studies, in which authors often see the need to define the term "Ideology", is that they do not do so based on its conceptual specificity, or, as Max Weber would say, based on an ideal type, but with the concrete cases they are analysing in mind. They often fail because they take the ontic aspects of concrete ideologies for the ontological level of Ideology as a notion, which is a significant theoretical mistake. Significant because the practice of a certain political group with a certain ideology cannot necessarily dictate all future political behaviours by other groups, as each ontic political experience has particularities that depend on a historical, precarious and contingent context.

Subjects assume ideological positions that guide their conduct. Thus, when we consider political groups with certain ideologies, we are dealing with ideology at the ontic level. However, the ontic level does not itself determine the ontological level. This means that we cannot take a concrete ideology in order to define Ideology, that we cannot take an effect for its cause and, lastly, that we cannot take the ontic to define the ontological.

The initial point we would like to make, as per Althusser (1985), is that Ideology has no history because it is itself omnipresent and transhistorical. To Althusser, "ideology is eternal" (1985, p. 85). Therefore, it does not have an actual end. We are, by nature, ideological and symbolic beings, which allows us to state two facts: 1) in general terms (the ontological level), there will always be Ideology; and 2) in concrete terms (the ontic level), ideologies are born, undergo variations and die out. The notion of ideology in Laclau's theory (LACLAU and MOUFFE, 1985; LACLAU, 1990) articulates at once the two points above. In the author's words:

The ideological would consist of those discursive forms through which a society tries to institute itself as such on the basis of closure, of the fixation of meaning, of the non-recognition of the infinite play of differences. The ideological would be the will to 'totality' of any totalizing discourse. And insofar as the social 
is impossible without some fixation of meaning, without the discourse of closure, the ideological must be seen as constitutive of the social. The social only exists as the vain attempt to institute that impossible object: society. Utopia is the essence of any communication and social practice (LACLAU, 1990, p. 92).

The above excerpt leads us directly back to the discussion in the last section, that is, about the impossibility of normatively forecasting the most appropriate solution for socio-political issues. Such a type of normativity seeks to control situations which are, in truth, uncontrollable, given we are faced with a social whose meanings cannot become objective, that is, discursively complete and transparent to comprehension. All attempts at fixing meaning, at carrying out their final suture, are always in vain, impossible. It is precisely regarding this that Laclau speaks of the "impossibility of society".

However, in spite of a fixation of meaning being impossible, at the same time it is required and necessary. Its necessity arises from the fact that in all political ideology there lies a "will to totality". Thus, the search for a conformation of the social according to its own worldview is characteristic of political discourse, because political discourse is imbued with ideology. The reason is this: since an "ideological certainty" regarding the best (albeit momentary) political form to be followed exists - which Laclau calls "closure of discourse" -, a political party's politico-discursive task, e.g. in a democracy, is to try to hegemonise its own view of society in electoral agonism. As we live democratically, that is, presupposing a series of concurrent ideologies, there is no way one of them can promote a complete closure of meaning. As we mentioned above, at the same time that such a fixation is impossible, it is equally necessary for an additional reason: establishing a certain ideological view in a democratic political space is vital for there to be order, for governability to exist. In this way, ideologies at the ontic level, that is, linked to daily political practice, are always precarious and contingent and threatened by opposing ideologies. However, at the ontic level, Ideology, in the Althusserian sense, is omnipresent and transhistorical. This means that if we cannot live without the presence of Ideology, any attempt to eliminate it will always be in vain, as this could be interpreted as merely another ideology in action.

In analytical terms, according to Laclau (2000), the notion of ideology must be understood based on the idea of false representation. But this does not mean that this idea signifies a return to Marxism, for that would be a contradictio in adjecto. In the Marxian ideological conception, ideology is necessarily the opposite of truth, a semantic inversion of relations actually existing in a societal context ${ }^{2}$. This conception presupposes that the

2 This passage from Ideology exemplifies the point I am discussing: "and if in all ideology men and their circumstances appear upside-down as in a camera obscura, this phenomenon arises just as much from their historical life-process as the inversion of objects on the retina does from their physical life-process" (MARX and ENGELS, 1978, p. 25-26). 
inversion of meaning produced by the ideological phenomenon obliterates the reach of truth, of transparency and of the non-inverted view.

Thus, to Laclau (1990, 2000), to keep alive the idea of false representation in order to explain the ideological phenomenon means to say that there is nothing untrue to be made true, because what must be let go of, in this case, is the very conception that there is an absolute truth contrary to the numerous falsehoods that hide it. It is not through this lens that Laclau suggests that we understand the phenomenon of ideology. This renunciation of the truth/untruth dyad, however, is a merely analytical renunciation, meaning that we have to admit to it because we are basing ourselves on the presupposition that there are no meanings that can become objective, that is, fossilised for all eternity. To him, we live in an everlasting war of interpretations as an ontological presupposition of the social. It is in this sense that the truth or non-distorted meaning will never be attained.

We said that this renunciation takes place at the analytical level because at the level of political dispute, subjects perceive and act based on their (distorted) ideological views as if they were truths. It is in this sense that false consciousness must not be abandoned, as distorting the world is constitutive of social objectivity. It occurs because there is an identity-based renunciation of the recognition of the non-closure of social meanings, formed by the simultaneously impossible and necessary attempt to objectify the world ${ }^{3}$. This is a "constitutive distortion". Regarding this, the author establishes that:

(...) what we are dealing with is a constitutive distortion. That is, that we are positing both an originary meaning (for this is required by any distortion) and withdrawing it (for the distortion is constitutive). In that case, the only logical possibility of pulling together these two apparently antinomic dimensions is if the original meaning is illusory and the distortive operation consists in precisely creating that illusion - that is, to project into something which is essentially divided the illusion of a fullness and self-transparency that it lacks (LACLAU, 2000, p. 17).

Ideology materialises in discourse. Discourse, in its turn, should not be understood as the simple reflexion of a series of texts or utterances, in a merely linguistic dimension. Discourse is a category that unites words and actions that have a material nature, not a mental and/or ideal nature. Discourse is a practice - hence the idea of discursive practice -, as any actions undertaken by subjects, identities or social groups are significant actions.

3 Zizek's conception is similar: "This is probably the fundamental dimension of 'ideology': ideology is not simply a 'false consciousness', an illusory representation of reality, it is rather this reality itself which is already to be conceived as 'ideological' - 'ideological' is a social reality whose very existence implies the knowledge of it participants as to its essence - that is, the social effectivity, the very reproduction of which implies that the individuals 'do not know what they are doing'. Ideological is not the 'false consciousness' of a (social) being but this being itself in so far as it is supported by 'false consciousness'” (ZIZEK, 2005, pp. 46-47 - his italics). 
The social is therefore a significant, symbolic, overdetermined social. It does not arise as something to be revealed, unveiled - as if reaching the truth in its most transparent and final form were possible -, but as something to be understood in its myriad forms and from the many possibilities through which to reach multiple certainties, which are always contingent and precarious. Thus, the truly known real, as a possibility to be examined, as a transparent positivity, is an impossibility, given that it is signified in various forms by the overdetermined ${ }^{4}$ lenses of subjects. This conception of the real in multiple forms is the basis of the critique that Laclau makes of Marxism, as the latter is constituted not as a theory of overdetermination of the social but as a theoretical undertaking, which, at most, bases social relations on an evolutionist and economic determination in the last instance, thus simplifying them ${ }^{5}$. In short, we present the material, not the ideal nature of a discourse. However, for this piece of work, what matters is the following question: why should discourse be perceived from an ontological viewpoint ${ }^{6}$ ? Simply because it names the being of existence, as existence requires a series of symbolic relations in order to attain the status of being, and this is only possible through discursive articulation. "What is denied is not that such objects exist externally to thought, but the rather different assertion that they could constitute themselves as objects outside any discursive condition of emergence" (LACLAU and MOUFFE, 1985, p. 108).

Let us spend a little more time on this point so as to clarify the difference between being and existence in the context of this discussion. Such a distinction is crucial, as it indicates that at the same time as Laclau seeks to distance his theoretical contribution from an idealistic dimension, as we mentioned a short while ago, he also seeks to differentiate his thinking from a strictly realistic dimension. According to this philosophical view, realism is not reducible to ideology, "reality being the "way of being of things such as they exist outside the human mind or regardless of it"" (PORTINARO, 2007, pp. 17-18 - his italics).

4 Overdetermination is a term derived from psychoanalysis, especially Freudian psychoanalysis, which designates "the plurality of certain factors that generate a given final effect" (ZIMMERMAN, 2001, p. 392). Further, "overdetermination is the effect of the workings of two mechanisms: that of condensation, (which aggregates several factors as if they were just one) and that of dislocation (which can give greater or lesser apparent importance to an insignificant factor, as the most relevant factor is dislocated to it" (ZIMMERMAN, 2001, p. 392).

5 The idea of economic determination in the last instance, dear to Marxism, is the main criticism that Laclau uses to oppose Althusserian theory, even considering the fact that Althusser incorporated into his theoretical project the Freudian category of overdetermination, which is one way of widening the analytical reach of Marxist theory. However, this category lost its heuristic potential when Althusser did not definitively break with the Marxist dogma of economic determination in the last instance.

6 Laclau is clear regarding the ontological character of discourse: "Discourse is, in our perspective, a field of general ontology, that is, of a reflection on being as a being" (LACLAU, 2008a, p. 189 - his italics). 
In this sense, to Laclau, discourse has a realistic dimension marked by the notion of existence. Existence indicates the material reality of things, of objects. However, mere existence in itself does not have the capacity to explain its own being, which, therefore, does not exhaust itself and cannot be comprehended based only on its realistic dimension. We need to understand that existence only has a being if it is immersed in a symbolic, discursive dimension. And it always is. In political terms, the discursive dimension is polemical, a symbolic struggle undertaken to establish the being of existence. A simple example given by Laclau and Mouffe (1990) will aid the comprehension of the existence/being relationship present in discourse:

Now, turning to the term discourse itself, we use it to emphasize the fact that every social configuration is meaningful. If I kick a spherical object in the street or if I kick a ball in a football match, the physical fact is the same, but its meaning is different. The object is a football only to the extent that it establishes a system of relations with other objects, and these relations are not given by the mere referential materiality of the objects, but are, rather, socially constructed. This systematic set of relations is what we call discourse. (LACLAU and MOUFFE, 1990, p. 100 - their italics).

Hence, as well as a real dimension (existence), objects have a dimension of meaning (being), and both are constitutive and inseparable parts of discourse. The real is not realisable in itself, but requires discursive objectifications. Outside the discursive context, objects have no being, only existence (LACLAU, 1990). Furthermore, considering the political dimension, these meanings are not liable to being closed. The complete fixation of meaning constantly escapes us; it is always beyond our reach. Two fundamental reasons explain the inconstant nature of meaning - antagonism and dislocation. We will analyse them in the following section.

\section{Antagonism and dislocation: the limits of objectivity}

To understand antagonic logic, firstly, one must understand in what context the notion of antagonism is elaborated by Laclau and Mouffe in HSS (1985). The authors' main aim is to demonstrate that political relations are not built from struggles between finished identities. More specifically, they understand that we cannot consider political identities in the essentialist sense, that is, constituted previously to the antagonic relation itself. Rather than being a relationship between already given objectivities, antagonism is the very moment at which they are constituted. Antagonism is the condition of possibility of formation of political identities, not merely a battlefield that forms between two readymade forces. 
Laclau and Mouffe (1985) illustrate the logic of antagonism with the example of a landowner who expels peasants from his land. At the moment of expulsion, an antagonic relationship is established inasmuch as the landowner, through his action, is preventing the peasant from fully being a peasant (he becomes a landless peasant). Likewise, in the logic of antagonism we are not dealing with pre-constituted identities, but with those that have their own constitution denied, as the presence of the other makes their full constitution impossible. According to the authors: "It is because a peasant cannot be a peasant that an antagonism exists with the landowner expelling him from his land. Insofar as there is antagonism, I cannot be a full presence for myself" (LACLAU and MOUFFE, 1985, p. 125 - their italics). Antagonism is therefore an experience of negativity, a relationship that shows the limits of objectivity or of the full constitution of identities. David Howarth is clear on this:

The mere existence of antagonisms confirms their view that there are no necessary laws of history and no universal political agents motivated by preconstituted interests and identities. Instead, antagonisms introduce social experiences, such as 'failure', 'negativity', or 'lack', which cannot be accounted for by any positive or essentialist logic of society. They also reveal the contingency and precariousness of all identity and social objectivity, as any identity is always threatened by something that is external to it (HOWARTH, 2000, pp. 105-106).

Considering that discourse theory is based on the presupposition that discourses are constituted antagonically, that is, because of the real threat originating from other discourses, let us look more closely at the manner in which Laclau and Mouffe expound the concept of antagonism in HSS. Antagonism is presented through its theoretical-analytical difference from the notions of real opposition and logical contradiction (cf. COLLETTI, 1975).

According to Laclau and Mouffe (1985), real opposition indicates that 'A - B' are different terms whose positivities exist regardless of the relation they might have to each other. Real opposition takes place in the realm of real objects. As an example, the authors present a hypothetical car crash involving two vehicles and state that: “(....) it is clear that an antagonism cannot be a real opposition. There is nothing antagonistic in a crash between two vehicles: it is a material fact obeying positive physical laws" (LACLAU and MOUFFE, 1985, p. 123 - their italics).

Now, the idea of logical contradiction is represented by the formula 'A - not A'. According to this notion, the relationship between the two terms exhausts the reality of both. Logical contradiction occurs in the realm of propositions, of concepts. Yet contradiction does not result in antagonism since "we all participate in a number of mutually 
contradictory belief systems, and yet no antagonism emerges from these contradictions" (LACLAU and MOUFFE, 1985, p. 124).

After presenting the difference between "real opposition" and "logical contradiction", the authors explain what these categories have in common and what makes them completely different from the notion of antagonism. Real opposition and logical contradiction "share something, and that is the fact of being objective relations - between conceptual objects in the second case, and between real objects in the first" (LACLAU and MOUFFE, 1985, p. 124 - their italics). In other words, the authors are stating that in both cases we are talking about positivities, fully constructed objects that are totally complete and intelligible. We are therefore dealing with "objective relations", "objects already in existence" and "complete identities" (LACLAU and MOUFFE, 1985).

In the case of antagonism, something completely different is being referred to. Here there is no longer any reference to "objective relations", "already existing objects" or "complete identities", but to the opposite. Antagonism indicates that "the presence of the 'Other' prevents me from being totally myself" (LACLAU and MOUFFE, 1985, p. 125 - their italics). This means that when faced with a situation of this kind, one should always presuppose a relationship between incomplete identities, precisely because of the fact that the relationship established between them is antagonic. While "real opposition" and "logical contradiction" must be considered as relationships between positivities, in the case of antagonism, we see the limits of objectivity itself, which means that ultimately, what is antagonistic is outside, excluded and limits the complete positivity of that which it antagonises.

The status of antagonism is reduced after HSS. In NR, Laclau (1990) reorganizes its place in his thought. If previously antagonism was understood as the limit of a system's systematization, or even, the limit of meaning that the discursive system could reach given the presence of its antagonistic feature, from NR onwards this category loses that dimension. Laclau begins to admit that antagonism cannot be the limit of a system's constitution of meaning, since the very condition of an antagonic other already infers some type of symbolisation, some form of meaning production. Thus, "what I am not" and "what I antagonise against" are already part of a system of signification. In an interview given to Yannis Stavrakakis, Laclau argues:

There was a certain ambiguity in the way the category of antagonism was formulated in Hegemony and Socialist Strategy. Today I believe that the constitution of the other as antagonistic already presupposes a certain discursive inscription - in other words, conceiving the other as an enemy presupposes a prior identification of ourselves with a particular position within the framework of the Symbolic order [It also presupposes, in most cases, the imaginary-fantastic construction of both antagonistic poles]. That's why in my more recent work I moved 
my attention to the category of "dislocation" as a level prior to that of "antagonism" (STAVRAKAKIS, 2003, p. 324 - his italics).

Our understanding is that the introduction of the category of dislocation is a significant change in Laclau's discourse theory. Initially, the author does away with the privileged status of antagonism as the sole party responsible for constituting social relations, which remain political and contentious. Antagonism now appears as part of a system of signification, as a condition of identification, as something symbolised. The antagonistic other, the enemy, is no longer the "non-symbolised", but the very possibility of symbolisation, of identification.

As we have said, from NR onwards, Laclau develops the concept of dislocation and assigns it a central role in the series of notions that make up his theory. His use of this concept clearly marks the marriage of discourse theory with Lacanian psychoanalysis, which allowed the idea of political subjectivity as an alternative to structural development to be developed. Let us take a closer look at this.

Firstly, the marriage of Laclau's theory with Lacan's thought had already begun taking shape since the 1980s. In HSS, for example, the notions of nodal points, suture and articulation already announced this trend. However, his introduction of the idea of dislocation marks an important theoretical shift. If in HSS Laclau and Mouffe (1985) criticised Foucault, rejecting "the distinction between discursive and non-discursive practices" and stating that "every object is constituted as an object of discourse, insofar as no object is given outside every discursive condition of emergence" (1985, p. 107), from NR onwards the situation changes considerably. But in what sense?

According to Laclau, every object continues to be an object of discourse, given that it is also marked by the context of its constitution, even if its existence is due to its materiality. For example, as was mentioned earlier, a ball unarguably has a material existence, but that also goes hand in hand with a symbolic-discursive context. So, it is a football, a basketball, a volleyball or a tennis ball, depending on the discursive context in which it is contained. In this sense, the critique of the Foucauldian non-discursive remains the same for Laclau. Therefore, what changes when the dislocation category is introduced is not the status and the functioning of the logic of discourse and of the constitution of signification, but how to deal with a situation in which the very possibility of signification has reached its limit. Dislocation is the exact moment of the impossibility of signification. Dislocation is the point at which Laclau executes the marriage of his theory with the Lacanian Real ${ }^{7}$.

7 Stavrakakis is absolutely clear on this aspect: "dislocation, by replacing antagonism as the kernel of the political, can only be understood as an encounter with the Lacanian real par excellence. Both are unrepresentable; both are at the same time traumatic/disruptive and productive. Dislocations are traumatic in the sense that they "threaten identities" and they are productive in 
The Lacanian Real is precisely that which cannot be symbolised, the impossibility of producing meaning. On the Real in Lacan, Homer argues:

The difficulty of understanding the real is partly due to the fact that it is not a 'thing'; it is not a material object in the world or the human body or even 'reality'. For Lacan, our reality consists of symbols and the process of signification. Therefore, what we call reality is associated with the symbolic order or 'social reality'. The real is the unknown that exists at the limit of this socio-symbolic universe and is in constant tension with it (HOMER, 2005, p. 81).

As we have mentioned above, dislocation, according to Laclau, is precisely the moment of the Real, that is, of the unknown, of the impossibility of signification. If previously Laclau and Mouffe (1985) understood this moment as antagonism, which Zizek correctly refutes $^{8}$ as antagonism is part of the very process of signification, from NR onwards the moment of this impossibility is represented by the notion of dislocation.

To reflect on a certain discursive structure requires a set of sedimented hegemonic meanings that constitute a certain order. This order evidently presupposes a series of antagonisms, given that politically, every discursive constitution is, on one hand, an act of inclusion of meaning, but on the other, a series of other exclusions. For example, a democratic State has a number of constitutive characteristics (universal suffrage, individual rights etc.) at the same time as it presupposes its own exclusions (xenophobic discourses, racism etc.). We are evidently not dealing with fully constituted discourses, given that they are always liable to be resignified and that these resignifications reflect the validity of the notion of hegemony (in order for there to be hegemony there must necessarily be counter-hegemony). A democratic discourse is always threatened by non-democratic practices and the idea of democracy is itself under constant negotiation and the object of endless argument. Thus, according to Laclau and Mouffe (1985), discursive logic is the result of articulatory practices that fix partial meaning through nodal points that articulate

the sense that they serve as "the foundation on which new identities are constituted." Similarly, the traumatic real always disrupts all attempts at symbolization; and yet it never ceases to call for new symbolizations. It is clear that the emergence of this concept of real dislocation as the kernel of the political is one of the most important products of Laclau's dialogue with psychoanalysis and one which directly links his argument on the impossibility of society with the irreducibility of the real in Lacanian discourse" (STAVRAKAKIS, 2003,p. 324).

8 Zizek has noticed this attempt by the authors of HSS to give the notion of antagonism the status of the Lacanian Real: "The real achievement of Hegemony is crystalized in the concept of 'social antagonism': far from reducing all reality to a kind of language-game, the socio-symbolic field is conceived as structured around a certain traumatic impossibility, around a certain fissure which cannot be symbolized" (ZIZEK, 1990, p. 249 - his italics). 
elements/moments. Any discursive constitution symbolises, structures and restructures meaning, as we are dealing with a process of constant signification.

The moment at which dislocation takes place is different. It occurs precisely when the structure cannot process, cannot semantise the new, whose signification therefore escapes it. Dislocation is thus an encounter with the Real, the moment at which discourse reaches the limit of its meaning. In socio-political terms, a dislocated structure is one that experiences a moment of crisis, of great jeopardy. Dislocation precedes signification; it is external to it and therefore external to antagonism - it is a traumatic experience that disarranges the structure, which needs to be recomposed from new processes of signification. Thus, we are talking about processes of signification substituting other processes of signification because of a structural fault caused by dislocation, that is, precisely because of the impossibility of signification.

If we cannot attain the Real because the real cannot be signified, dislocation is the evidence of a structure's incompleteness, of the impossibility of its final structuring. If the Real exists but cannot be symbolised and if the structures are structured from processes of signification, then, at most, we are always faced with incomplete structures, marked by the possibility of the trauma of dislocation. In short, they are structures of lack. It is at this moment that the subject assumes a central position. According to Laclau: "the location of the subject is that of dislocation. Thus, far from being a moment of the structure, the subject is the result of the impossibility of constituting the structure as such - that is, as a self-sufficient object" (LACLAU, 1990, p. 41). According to Howarth:

It is this 'failure' of the structure to confer identity on social actors that 'compels' the subject to act. In this sense, the subject is not simply determined by the structure; nor, however, does it constitute the structure. The subject is forced to take decisions - or identify with certain political projects and the discourses they articulate - when social identities are in crisis and structures need to be recreated. It is in the process of this identification that political subjectivities are created and formed (HOWARTH, 2000, p. 109 - his italics).

So, from a dislocated structure, a need is generated for it to be restructured from new meanings or from the reactivation of meanings already in existence. It it is at this moment that antagonism assumes a definitive place in discourse theory - as part of processes of signification, of constitution of new forms of inclusion, but also of exclusion of discursive meanings. In the words of Laclau: (...) the response to the dislocation of the structure will be its recomposition around particular nodal points of articulation by the various antagonistic forces. Centring - the action of 'centring' - is therefore only possible through dislocation and unevenness. To repeat: dislocation is both the condition of possibility and impossibility of a centre at the same time (LACLAU, 1990, p. 40). 
Therefore, the structure's (re)centring is necessarily related to the constitution of new antagonisms and new hegemonic processes. Although social antagonism loses its centrality in discourse theory to dislocation, it is still a conditio sine qua non to the possibility of the existence of discourses.

\section{The place of normativity in Ernesto Laclau's thought}

Broadly understood as a set of precepts or politically desirable situations, the normative has a limited place in discourse theory. Considering the more general context of Laclau's thought, even with the category of dislocation taking the privileged status of that of antagonism, we must not forget that we are dealing with a post-foundationalist theoretical perspective, that is, we are constantly questioning theoretical projects that seek to structure themselves on an ultimate ground, whatever that might be.

We could say that the impossibility of finding an ultimate ground is at the ontological basis of Laclau's political thought. His entire theoretical trajectory from HSS until On Populist Reason (2005) possesses this essential characteristic: there is no way to escape from the antagonism, precariousness and contingency that dominate socio-political relations. This conviction marks all the analytical categories of discourse theory, which are based on a post-foundationalist system of thinking. This is the main reason for Laclau having been quite critical of the Marxist tradition, a great influence on his own thought, especially the Althusserian current. This is the also main reason for which he disagrees with deliberative political solutions, based on instrumental reason, on the projection of ideal, artificially constructed scenarios. The core of Laclaunian criticism, whether aimed at Marxism or deliberation, is the fact that each one seeks, in its own manner, to "domesticate", to dominate social meanings, when they cannot attain an ultimate ground. Furthermore, Laclau suspects that solutions of this type - which do not take into account other possibilities for dealing with the challenges of the political world - are one step away from totalitarian practices:

An apodictic decision, or, in a more general sense, a decision that claims for itself an incontestable 'rationality', is incompatible with a plurality of points of view. If the decision is based on a reasoning of an apodictic character, it is not a decision at all: a rationality that transcends me has already decided for me, and my only role is that of recognizing that decision and the consequences that unfold from it. This is why all the forms of radical rationalism are just a step away from totalitarianism (LACLAU, 1990, p. 194).

Discourses that promise final political solutions and that are constructed with ideal, interesting and desirable arguments, which promise possible new worlds, capture 
followers for two main reasons. Firstly, because they present a set of concepts, solutions and rhetorical arguments that are based on a genuine desire to resolve numerous social and political disparities. The other reason is precisely because of what we previously discussed regarding Ideology. We saw that, to Laclau, "the ideological would be the will to 'totality' of any totalizing discourse" (1990, p. 92). This will is present in all discourses, as well as in all the subjects involved in them. The Laclaunian criticism of normative proposals is obviously not because they are "incorrect" or even unviable. The main point of the criticism lies precisely in the fact that they should always be perceived on the ontic level, which invariably means that they are political decisions made in a field marked by indecisiveness. This means that a normative proposal will never be able to dominate all social meanings, never eliminate all existing antagonisms. In order to actually be decisions, all decisions must inhabit an undecidable world, that is, one marked by the myriad possibilities of other decisions occurring. An apodictic decision, in this sense, is not a decision but an ever-inefficient attempt at closing down all other normative proposals that the world's contingency makes possible. In this case, as Laclau emphasises, we are one step away from totalitarian will.

Having said that, how is it possible to think about the normative with discourse theory as a presupposition? Before attempting to answer this question, we must make a preliminary observation. In the beginning of this text, we presented Laclau as a political theorist, in the sense that his work seeks to explain the logic of the political phenomenon at an ontological level and, at the same time, to propose normative scenarios. However, he always has in mind the notion that all political action, all decisions, are always marked by precariousness and contingency. These characteristics are present, for example, in all the notions presented in this article. They serve to say more or less the following: all right, you can think whatever you want normatively, but all political decisions always take place at the ontic level and are therefore marked by their own finitude, given the ontology of the political. Ideology, antagonism, contention around the meaning of the being of existence and events of structural dislocation are not simply eradicable through normative wills. On the contrary, they are ineradicable for as long as the political world exists.

The Laclaunian perception of the finitude of the ontic decision - in the sense that a complete fixation of meaning always escapes us, given the infinitude of the social - lies at the core of his criticism of the Habermasian tradition, for example. In response to Aletta Norval, who attempts to elaborate a normative political theory from a deliberative and post-structuralist perspective, Laclau clearly presents the distinction between ontological and ontic, as well as demonstrating the theoretical limitation of taking the former for the latter:

I am now in a position to answer Norval's charge that, in my analysis, I 
have neglected the question of democratic institutional arrangements, and that this results from my exclusive emphasis on the ontological side of the question and my concomitant lack of consideration of the ontic aspects. My answer is that a general theory of democracy can only specify its constituent dimensions, but has to be very cautious about their institutional articulation. Precisely because this articulation is a contingent historical matter, it cannot be determined at the level of a general theory of democracy. To try to proceed to that determination within general theory would lead to results which are the opposite of what Norval tries to achieve - i.e. to transform a particular ontic arrangement into an ontological category. This is the best prescription to end in ethnocentrism and sociological essentialism (LACLAU, 2004, p. 298).

Given the scenario presented in this quote, the normative expectations that open up from discourse theory cannot be regarded sensu stricto, as in the case of deliberative approaches. If one cannot take the ontological for the ontic, real political experiences are necessarily limited and surrounded by historical precariousness and contingency. This means that the normative depends on the moment of its occurrence and varies according to the situation. It cannot be conceived a priori, outside of the context in which it emerges.

The normative therefore arises with a practically unrestricted degree of freedom. On one hand, because we cannot speak of a privileged political subject, such as in the case of the proletariat in the Marxist tradition, and on the other, because the normative possibilities are many as they are directly related to the occurrence of concrete political situations. Yet this theoretical approach also takes into consideration the possibility of political advances retrogressing, precisely because of the fact that the possibilities of political change are manifold. For example, the advances in civil rights achieved by the feminist struggle in the $20^{\text {th }}$ century are not forever - they are always surrounded by the threat of retrogression. "The feminist or ecological political subjects, for example, are up to a certain point, like any other social identity, floating signifiers, and it is a dangerous illusion to think that they are assured once and for all, that the terrain which has constituted their discursive conditions of emergence cannot be subverted" (LACLAU and MOUFFE, 1985, p. 141 - their italics).

The only way to guarantee consistent political advances lies in the constant (re)negotiation between identities articulated from hegemonic discourses. In this case, taking the quotation above as an example, ecological and feminist subjects must join their identity demands with other subjects around hegemonic discourses able to ensure a maximum continuation of the victories attained and, along with other demands for more social inclusion, promote strategic movements so as to further advance politically. Yet there are no effective normative prescriptions that can be stipulated before a given political situation - it all depends on the context in which the political demands themselves emerge. Thus, there are no ready-made politico-normative formulas: there is no world to invent prior to 
its own occurrence. It is in this sense that Laclau is a political theorist. He does not believe that theory should be disconnected from political practice, as both are ultimately one and the same thing.

We believe that, as an ontological theory of the political, the fundamental role of Laclaunian theory is to outline the general lines of the political phenomenon. Bearing in mind its interpretation from a post-foundationalist position - which necessarily presupposes ontic relations that are always contingent and precarious -, it is impossible to think about normative scenarios that will be constant once they are implemented. This means that all political achievements must be constantly defended. In the same way that a struggle does not actually have an end, all political change is possible: there is no harm that can be perpetrated forever with impunity. For discourse theory, the sole ground possible, in the sense of Heidegger's Urgrund, is the abyss itself ${ }^{9}$.

\section{Final considerations}

As we have seen, Ernesto Laclau's theoretical-political contribution is clearly located at the ontological level, as he himself has stated on many occasions (LACLAU, 2008b). Laclau develops a reflection on the political being, seeing any social arrangement as fundamentally contingent and precarious. We understand that this perception does not leave any space for constructing essentially stable and lasting ontic scenarios, given that the latter are inexorably contaminated by the instability of the political. Hence his recurrent criticisms of Marxism's political solutions and of numerous deliberative postulations. Although normatively very diverse, both have a feature in common: when seen through the lens of discourse theory, they seek to "freeze" the instability of political dynamics and aim for their closure. However, this instability of the political, which initially can understandably demotivate some of the spiritual heirs of Enlightenment, opens a whole new range of perspectives from which to consider political articulation between collective identities. For Laclau, the struggle against the most distinct forms of oppression - and this would be his theory's strong normativity - must be the result of wide articulation among the discourses of the oppressed, antagonised by excluding political practices. It is therefore not a case of seeking out an arche, an explanatory origin of existing inequalities and, based on that knowledge as a type of diagnosis of a social disease, seek out the cure. Perhaps that would be "the best of both worlds", were this not a legacy of essentialist and reductionist ways of thinking. To Laclau, on the contrary, there is no cause, no origin that can explain

9 The Heideggerian idea of abyss as a ground has been a constant in Laclau's more recent thought (LACLAU, 2013). 
exclusion, since it is overdetermined in various ways: there are many oppressors for the most varied of reasons. Thus, only articulation between different identities will make a political struggle effective. This articulation will result in a hegemonic process, which is nothing short of the construction of a universal discourse able to represent the most different of demands for a collective emancipation. In this way, basing ourselves on the Laclaunian proposal, it is not a matter of thinking only - and idiosyncratically - about the political emancipation of women, ethnic minorities, sexual minorities, etc., but also about the construction of a common political project, because it is only by articulating their differences that they will be strong enough to fight against the many forces that oppress them. It is only possible to think about emancipatory projects based on the political solidarity of those involved.

By way of a conclusion, we would like to cite a quote at the end of one of the most thought-provoking essays by Ernesto Laclau. ${ }^{10}$ At the peak of his argumentation, he quotes a proverb well known in the deserts of Libya and mentioned by Ortega y Gasset, which, in our opinion, is remarkably related to the idea of solidarity present in any hegemonic articulation: if thirst is the common enemy, "drink from the well and leave the place to your neighbour" (LACLAU, 1990, p. 84).

Translated by Priscila Moura

Submitted in June 2013

Accepted in February 2014

\section{References}

ALTHUSSER, Louis (1985), Aparelhos ideológicos do estado. Rio de Janeiro, Edições Graal.

COLLETTI, Lucio (1975), Marxism and the dialectic. New Left Review, vol. I, No 93, Sep/Oct, pp. 1-29.

HOMER, Sean (2005), Jacques Lacan. New York, Routledge.

HOWARTH, David (2000), Discourse. Buckingham, Open University Press.

LACLAU, Ernesto (1990), New Reflections on the Revolution of Our Time. London, Verso.

LACLAU, Ernesto (1994), Introduction. In: E. Laclau (ed.), The making of political identities. London, Verso.

LACLAU, Ernesto (1996), Emancipation(s). London, Verso.

LACLAU, Ernesto (2000), Misticismo, retórica y política. Buenos Aires, Fondo de Cultura Económica.

10 We are referring to the essay New reflections on the revolution of our time (Laclau, 1990). 
LACLAU, Ernesto (2004), Glimpsing the future. In: CRITCHLEY, S. \& MARCHART, O. (editors), Laclau: a critical reader. London, Routledge.

LACLAU, Ernesto (2005), On populist reason. London, Verso.

LACLAU, Ernesto (2008b), Posfácio. In: MENDONÇA, D. \& RODRIGUES, L. P. (org.), Pósestruturalismo e teoria do discurso: em torno de Ernesto Laclau. Porto Alegre, EdiPUCRS.

LACLAU, Ernesto (2013), Representación y movimientos sociales, Revista www.izquierdas.cl, $\mathrm{n}^{\circ} 15$, April 2013, pp. 214-223. Available at: http://www.izquierdas.cl/revista/wp-content/ uploads/2013/04/ERNESTO-LACLAU.pdf. Retrieved on: 9 Dec, 2013.

LACLAU, Ernesto \& MOUFFE, Chantal (1985), Hegemony and socialist strategy: towards a radical democratic politics. London, Verso.

LACLAU, Ernesto \& MOUFFE, Chantal (1990), Post-Marxism without apologies. In: LACLAU, E., New Reflections on the Revolution of Our Time. London, Verso.

MARCHART, Oliver (2004), Politics and the ontological difference: on the 'strictly philosophical' in Laclau's work. In: CRITCHLEY, S. \& MARCHART, O. (editors), Laclau: a critical reader. London, Routledge.

MARCHART, Oliver (2007), Post-foundational political thought: political difference in Nancy, Lefort, Badiou and Laclau. Edinburgh, Edinburgh University Press.

MARX, Karl \& ENGELS, Friedrich (1978), A ideologia alemã. Volume I. Editorial Portugal/Brasil, Presença/Livraria Martins Fontes.

NORVAL, Aletta (2007), Aversive democracy: inheritance and originality in the democratic tradition. Cambridge, Cambridge University Press.

PORTINARO, Pier Paolo (2007), El realismo político. Buenos Aires, Ediciones Nueva Visión.

STAVRAKAKIS, Yannis (2003), Laclau with Lacan: comments on the relation between discourse theory and Lacanian psychoanalysis. In: ZIZEK, S. (ed.), Jacques Lacan: critical evaluations in cultural theory (Volume III - Society, Politics, Ideology). London, Routledge.

ZIMMERMAN, David E. (2001), Vocabulário contemporâneo de psicanálise. Porto Alegre, Artmed Editora.

ZIZEK, Slavoj (1990), Beyond discourse-analysis. In: LACLAU, E., New Reflections on the Revolution of Our Time. London, Verso.

ZIZEK, Slavoj (2005), El sublime objeto de la ideología. Buenos Aires, Siglo Veintiuno Editores Argentina. 